\title{
PEMANFAATAN BLOG SEBAGAI SARANA PROMOSI KAMPUNG WISATA DI MASA PANDEMI
}

\author{
Yana Shanti Manipuspika'), Tantri Refa Indhiarti ${ }^{1)}$, Emy Sudarwati ${ }^{1)}$ \\ 1)Program Studi Sastra Inggris, Fakultas IImu Budaya, Universitas Brawijaya, Malang, Jawa Timur, Indonesia \\ Corresponding author: Yana Shanti Manipuspika \\ Email: yana_shanti@ub.ac.id
}

Diterima 11 Oktobe 2021, Direvisi 02 November 2021, Disetujui 02 Novemebr 2021

\begin{abstract}
ABSTRAK
Kegiatan pengabdian kepada masyarakat ini dilaksanakan di Kampung Biru Arema (KBA) Malang sebagai kelanjutan dari kegiatan pengabdian tahun sebelumnya. Tujuan dari kegiatan ini adalah untuk lebih mempromosikan KBA sebagai salah satu kampung wisata di Malang melalui media blog. Metode yang diterapkan ialah melalui pelatihan penulisan artikel blog untuk memberikan gambaran menarik terkait kampung wisata. Sebagai kelanjutan dari kegiatan tahun lalu, tim pengabdian dapat melihat bahwa media sosial KBA sudah lebih hidup dan lebih berwarna dengan postingan baru. Blog resmi yang telah direvitalisasi pada kegiatan pengabdian kali ini telah mampu mempromosikan KBA dengan lebih baik lagi karena menampung berbagai kegiatan masyarakat kampung wisata ini. Artikel-artikel baru yang ditulis oleh anggota karang taruna KBA juga cukup menarik, sehingga diharapkan para pembaca yang mencari informasi terkait KBA memperoleh lebih banyak informasi. Pada akhirnya, KBA akan semakin dikenal luas dan dapat kembali mendatangkan pengunjung saat situasi pandemi sudah mereda.
\end{abstract}

Kata kunci: blog; kampung wisata tematik; kampung biru arema; promosi; situs web.

\begin{abstract}
This community service activity was carried out in Kampung Biru Arema (KBA) as a continuation of the previous year's community service. The purpose was to further promote KBA as one of the thematic tourism kampung in Malang. Updating the content of the website, in this case the KBA blog, was the focus of this year's agenda. The method used was by giving training to the youth members of KBA to create engaging articles for the official blog. As a continuation of last year's activity, the community service team has revealed that KBA's social media is more lively and more colorful with new posts. The official blog which has been revitalized is able to better promote KBA. The new articles written by members of the KBA youth organization (Karang Taruna) are also interesting and engaging, so it is hoped that readers who are looking for information related to KBA will gain more insights about this kampung. In the end, KBA will be more widely known and can bring back visitors when the pandemic ends.
\end{abstract}

Keywords: blog; thematic tourism kampung; Kampung Biru Arema; promotion; website.

\section{PENDAHULUAN}

Kota Malang terkenal dengan puluhan kampung tematiknya yang menjadi magnet wisatawa (https://www.antaranews.com). Salah satu yang paling populer di media sosial adalah Kampung Warna-Warni Jodipan di kawasan Embong Brantas. Di seberangnya kini juga ada kampung tematik lainnya, yakni Kampung Biru Arema (KBA). KBA diresmikan pada 6 Februari 2018 oleh Walikota Malang, Mochamad Anton. Kampung ini menjadi daya tarik tambahan dari kampung-kampung tematik yang letaknya tak jauh dari stasiun kereta api Kota Baru Malang.

KBA merupakan bagian dari penanganan kawasan permukiman kumuh sebagai bagian rencana pembangunan nasional. Kampung Biru asalnya adalah Kampung Embong Brantas, Jalan Gatot Subroto, Kota Malang. Salah satu alasan mengapa Kampung Biru Arema (KBA) memilih warna biru sebagai warna utama dan satu-satunya tak lain karena warga kampung tersebut mengidolakan Arema, klub sepakbola kebanggaan kota Malang. Kampung Biru ini juga terinspirasi dengan Kota Biru di Maroko atau Santorini di Yunani di mana bangunannya berwarna (https://kampungbiruarema.blogspot.com/).

Sebagai salah satu destinasi wisata tematik, ternyata Kampung Biru masih memiliki beberapa kelemahan terutama dalam promosi daring. Promosi daring sangat dibutuhkan utamanya dalam masa pandemi seperti sekarang. Meskipun kampung ini telah memiliki 
akun media sosial resmi seperti Facebook dan Instagram, berbagai sarana promosi tersebut belum berjalan dengan aktif. Hal ini sangat disayangkan karena dalam masa pandemi, media daring berperan penting sebagai strategi solutif yang dapat dilakukan masyarakat di wilayah berpotensi pariwisata (Lidya dkk, 2020).

Masifnya penggunaan media sosial di Indonesia menjadi media promosi utama objek wisata, termasuk kampung wisata. Fenomena tersebut menunjukkan besarnya potensi dan antusiasme masyarakat untuk mendatangi objek wisata yang dipromosikan secara daring. Para pengelola objek wisata mempublikasikan fasilitas wisata melalui media sosial mampu meningkatkan nilai jual dan popularitas. Hal ini sejalan dengan penelitian Asri Sj, dkk (2014) yang menyatakan bahwa media sosial semakin luas digunakan sebagai saluran promosi pariwisata. Media sosial secara sederhana diartikan sebagai salah satu platform media daring untuk mendukung komunikasi secara interaktif. Istilah media sosial melingkupi beragam platform seperti blog, micro-blogging (seperti Twitter), jejaring sosial (seperti Facebook), Wiki (seperti Wikipedia), berbagi foto (seperti Flickr), berbagi video (seperti Youtube), jejaring suara (seperti Skype), berbagi musik (seperti Last FM), tinjauan produk dan jasa (seperti TripAdvisor), dan lain sebagainya.

Kegiatan pengabdian ini adalah kegiatan multi tahun. Tahun pertama kegiatan adalah 2019, dan tahun ke dua ialah pada 2020. Tim melaksanakan peremajaan akun Instagram pada tahun pertama, dan kali ini, tim melakukan pelatihan menulis blog untuk mendukung promosi pariwisata di KBA secara berkelanjutan. Hasil kegiatan pada tahun pertama menunjukkan bahwa promosi yang dilakukan oleh pengelola KBA yaitu dengan menggunakan sosial media berupa Instagram dan Youtube (Indhiarti dkk, 2020).

Untuk menunjang agar media sosial di Kampung Biru terus berjalan aktif, partisipasi warga KBA sangat diperlukan. Hal ini selaras dengan ide pengembangan wisata berbasis masyarakat atau yang dikenal dengan CBT (Community-based Tourism) dimana untuk menjadikan sebuah tempat wisata maju maka partisipasi masyarakat di daerah wisata sangat diperlukan. Hal ini seperti pendapat yang dikemukakan oleh Suansri (2003, dalam Rahayu dkk, 2016), yang mengatakan bahwa komponen CBT adalah: 1) mengenali, mendukung, dan mempromosikan kepemilikan masyarakat dalam pariwisata; 2) melibatkan anggota masyarakat dari setiap tahap pengembangan pariwisata dalam berbagai aspeknya; 3) mempromosikan kebanggaan terhadap komunitas bersangkutan; 4) meningkatkan kualitas kehidupan; 5) menjamin keberlanjutan lingkungan; serta 6) melindungi ciri khas (keunikan). Oleh karena itu, perlu adanya suatu pemantapan kemampuan menulis pengelola media sosial. Pengembangan potensi wisata KBA dengan memanfaatkan masyarakat KBA mutlak diperlukan untuk mencapai keberhasilan wisata yang diharapkan.

Dalam kehidupan modern, keterampilan menulis sangat dibutuhkan. Dengan memiliki keterampilan menulis tersebut seseorang dapat merekam, mencatat, meyakinkan, melaporkan, memberitahukan, serta mempengaruhi orang lain (Sari dkk, 2014). Semua tujuan itu dapat dicapai oleh orang-orang yang dapat menyusun pikirannya dan menyampaikannya dengan jelas. Melihat besarnya manfaat kemampuan menulis dalam mempromosikan sebuah tempat wisata, maka digagaslah program pelatihan menulis dengan tujuan promosi wisata KBA melalui media blog.

Kegiatan pengabdian dilaksanakan dengan memberikan pendampingan pada personil Karang Taruna KBA untuk menulis berita seputar wisata Kampung Biru untuk kemudian diunggah ke situs web KBA yang terintegrasi dengan akun Instagram resmi KBA. Hal ini akan sangat membantu dalam hal promosi Kampung Biru supaya lebih dikenal luas mengingat media sosial Instagram saat ini sangat digandrungi masyarakat dari berbagai usia. Terlebih hal ini dikaitkan dengan adanya pandemi Covid-19 yang membuat pengelola destinasi wisata melakukan banyak cara untuk dapat bertahan hidup. Salah satunya dengan memilih strategi tertentu untuk tetap mempromosikan destinasi wisata. Di sinilah momentum bagi pengelola untuk melakukan peremajaan destinasi dan peningkatan kapasitas sumber daya alam. Hal ini sejalan dengan Sung dkk (2012) yang menyatakan bahwa untuk pengembangan desa wisata dalam jangka panjang perlu dilakukan program pendampingan untuk meningkatkan kemampuan para pengelola wisata dalam aspek kepariwisataan dan teknologi pendukung.

\section{METODE}

Dalam melaksanakan kegiatan pengabdian, tim menjalankan beberapa tahapan yang dipaparkan sebagai berikut.

1. Observasi

Pada tahap ini, tim pelaksana menemui pihak terkait di KBA, yakni Ketua RW dan anggota Karang taruna yang menjadi administrator/ pengelola media sosial 
KBA, serta mengunjungi lokasi untuk memetakan kebutuhan masyarakat KBA. Kegiatan observasi ini sangat penting mengingat dari kegiatan inilah akan diperoleh peta kegiatan yang akan dilakukan.

2. Sosialisasi

Tahapan ini bertujuan untuk memberikan pemahaman tentang arti pentingnya media sosial dalam era digital informasi global bagi pengembangan kehidupan sosial, budaya, dan ekonomi masyarakat KBA.

Pada tahapan ini tim PkM melakukan kegiatan sosialisasi program kepada subjek binaan yakni warga KBA (Kampung Biru Arema). Tahapan sosialisasi ini bertujuan untuk memberikan pemaparan tentang program yang akan dilaksanakan di KBA. Tim PkM bertemu dengan tokoh pengurus KBA di Kampung Biru Arema untuk membicarakan program terkait. Tim disambut dengan baik oleh Ketua RW dan pengurus KBA setempat serta Ketua karang taruna. Pertemuan ini membahas prosedur pelaksanaan program yang akan dilakukan. Di tahun ini, pelatihan difokuskan untuk mengasah kemampuan menulis untuk mengisi blog resmi KBA.

3. Pelatihan

Pelatihan bertujuan untuk meningkatkan pengetahuan dan keterampilan pengelola media sosial. Dalam pelatihan, tim menggunakan metode praktek lapangan, yakni memperbaiki fitur-fitur mana saja yang perlu dimasukkan dalam media sosial. Selain itu juga diberikan pendampingan kepada anggota Karang Taruna dalam realisasi pengisian materi pada media sosial KBA. Dikarenakan adanya kondisi pandemi Covid-19, kegiatan pelatihan dan pendampingan disepakati untuk dilakukan secara kombinasi daring dan luring. Pelatihan pertama dilaksanakan secara luring di balai RW, sedangkan kegiatan selanjutnya dilaksanakan secara daring.

4. Pendampingan

Tim pengabdian melakukan pendampingan dalam pembuatan/ pengunggahan artikel berita di media sosial KBA, dalam hal ini adalah blog resmi. Tim secara berkesinambungan melakukan evaluasi artikel berita yang disajikan oleh pihak KBA dalam media sosialnya. Pendampingan ini dimaksudkan untuk menjaga kualitas informasi yang disajikan untuk lebih menumbuhkembangkan reputasi media sosial KBA.

\section{Evaluasi}

Setelah melakukan pendampingan penulisan, tim PkM melakukan analisis terhadap artikel yang diukur dengan melihat unsur substansi isi, struktur, pilihan kata, pengembangan paragraf dan mekanik penulisan. Berikut ini unsur yang dinilai:
a. Kesesuaian tema
b. Gagasan
c. Argumentasi
d. Penulisan

\section{HASIL DAN PEMBAHASAN}

Untuk mengawali kegiatan pembaharuan konten website, tim PkM mengadakan kegiatan pelatihan kepada 5 anggota karang taruna mengenai apa saja yang perlu ada dalam situs resmi, dalam hal ini blog, sebuah kampung wisata.

Dalam kegiatan pelatihan ini, tim PkM memberikan beberapa contoh destinasi wisata yang semula biasa saja namun menjadi terkenal karena cara membawakan berita tentang tempat itu yang baik. Berdasarkan pengamatan tim PkM, media promosi KBA memang sangat minim jika ditinjau dari aspek berita. Hal ini dapat dilihat dari minimnya jumlah serta tanggal postingan di berita terdahulu yaitu Januari 2018. Dapat ditarik kesimpulan bahwa warga KBA belum secara penuh memaksimalkan kekuatan berita daring sebagai media promosi yang sebenarnya sangat efektif untuk mendongkrak potensi wisata suatu wilayah.

Memperhatikan bahwa isi blog resmi kampung wisata ini masih kurang berisikan artikel yang 'menjual' wisata KBA, maka kegiatan pengabdian berfokus untuk melatih pemuda pemudi KBA untuk aktif menulis di blog tersebut.

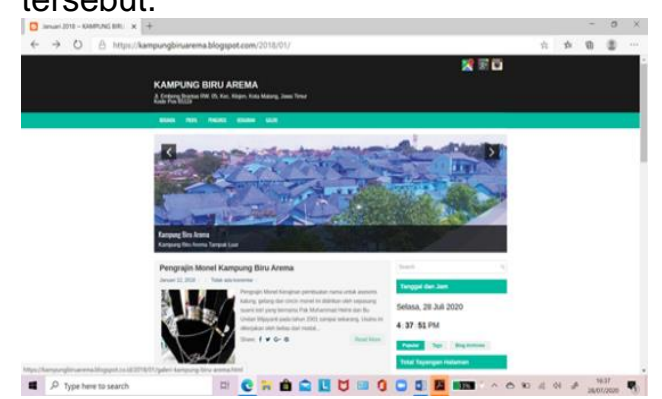

Gambar 1. Blog resmi KBA sebelum kegiatan pengabdian

Materi pelatihan kali ini mengulas mengenai cara menulis konten yang berkualitas dan menarik. Bila seseorang menulis konten yang orisinil, mesin pencari akan membantu situs web nya memperoleh lebih banyak ekspos. Untuk mengembangkan konten berkualitas, ada beberapa langkah yang dapat 
ditempuh. Pertama, pengurus media sosial KBA perlu membuat konten yang orisinil. Konten orisinil sejalan dengan Google dan pengunjung situs pada umumnya. Orisinalitas penulis merupakan hal yang mendasar, artinya jika menggunakan konsep atau postingan yang sama lagi dan lagi berarti tidak orisinil.

Kedua, penulis perlu fokus untuk menciptakan headline yang kuat. Headline yang baik membangkitkan minat dan mengundang pembaca. Pada umumnya, 80\% orang akan membaca headline berita, namun hanya $20 \%$ dari mereka yang akan membaca seluruh isi konten. Sehingga, headline sama pentingnya dengan artikel itu sendiri. Seperti disampaikan oleh Kertanegara (2018), fenomena penggunaan Clickbait Headline untuk mendapatkan KPI (key performance indicator) yang tinggi ini mulai banyak muncul. Clickbait headline yakni headline yang atraktif namun terkadang menjebak keingintahuan dari para pembacanya. Headline seperti ini sebaiknya dihindari dalam blog resmi.

Langkah ketiga terkait dengan penyampaian jawaban. Ketika orang menggunakan mesin pencari, yang mereka inginkan adalah jawaban, dan menjadi tugas mesin pencari untuk memberikan jawaban. Sama halnya ketika orang membaca sebuah postingan blog, melihat infografik, atau menonton sebuah video, mereka menginginkan jawaban untuk mendapat pengetahuan. Oleh karena itu, konten perlu diatur supaya mudah dibaca agar orang bisa menangkap bagian yang penting dengan cepat.

Aspek selanjutnya yakni akurat dalam melaporkan dan mengambil informasi. Blog merupakan salah satu refleksi dari organisasi. Sehingga apapun yang ditayangkan dalam satu blog harus dipastikan mampu menarik pembaca untuk melihat isi lengkapnya. Beberapa orang merupakan tipe visual, lainnya mungkin lebih ke tipe pendengar. Baik gambar, video, atau diagram, dapat membantu mengilustrasikan apapun yang dituliskan dalam sebuah artikel (Widjajanto, 2013).

Tidak ada yang lebih baik selain postingan blog atau artikel yang singkat dan langsung pada inti persoalan yang berisi informasi. Sehingga yang perlu menjadi fokus bukanlah jumlah kata. Postingan blog yang lebih panjang tidak berarti postingan yang lebih baik. Dan sering kali, membuat postingan blog yang pendek lebih sulit dan lebih membutuhkan waktu.

Blog atau situs resmi Kampung Biru Arema sebagai salah satu 'wajah' sebuah kampung wisata perlu diperbarui secara teratur dengan konten berkualitas. Banyak situs dengan konten terbaik diperbarui secara berkala. Situs yang memposting lebih sering umumnya memiliki gelombang pengunjung lebih kuat.

Setelah melaksanakan pelatihan awal akan pentingnya pengembangan dan promosi wisata melalui blog, tim melaksanakan pendampingan dalam penulisan artikel untuk situs resmi KBA karena hal ini berkaitan erat dengan kegiatan komunikasi dan publikasi untuk membangun citra KBA. Pembaruan konten situs web juga dilakukan untuk mengakomodasi keinginan wisatawan yang dalam memutuskan destinasi wisata mana yang akan dikunjungi dapat dipengaruhi oleh citra yang dibangun misalnya dalam pemberitaan media.

Dalam sesi pendampingan, peserta pelatihan menyampaikan mengenai beberapa kegiatan yang KBA lakukan selama masa pandemi Covid-19. Tema ini diambil untuk menunjukkan bahwa KBA merupakan salah satu destinasi wisata yang tangguh. Dengan kata lain, KBA memiliki suatu kemampuan untuk melawan dan memulihkan diri dari efek bahaya pandemi dengan cara efisien.

Kegiatan-kegiatan tersebut kemudian dijadikan topik untuk penulisan konten berita daring KBA. Peserta melakukan brainstorming terlebih dahulu untuk mencari topik yang menarik untuk diangkat menjadi berita. Setelah melalui diskusi, peserta mengusulkan empat judul untuk bahan berita daring yang akan ditulis yaitu dengan tema disinfektan, wastafel portable, usaha jamu anti korona, dan pembuatan hand sanitizer rumahan.

Salah satu berita yang ditulis oleh peserta adalah mengenai kegiatan pemasangan wastafel portable di KBA untuk menunjang GERMAS (Gerakan Masyarakat Hidup Sehat) dimana salah satu aspeknya adalah dengan mencuci tangan menggunakan sabun dan air mengalir. Wastafel portable ini diletakkan di pintu masuk KBA sehingga siapapun yang datang ke KBA dapat melakukan satu langkah mencuci tangan sebelum masuk lebih jauh ke kampung wisata ini. Berikut adalah artikel terkait yang telah dimasukkan dalam blog KBA.

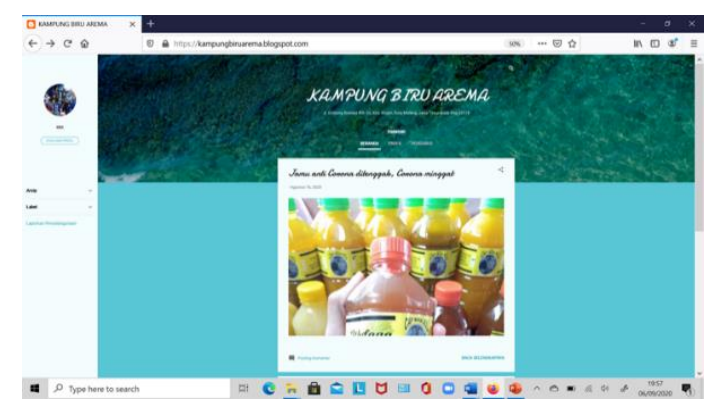

Gambar 2. Blog resmi KBA setelah diperbarui dalam kegiatan pengabdian 


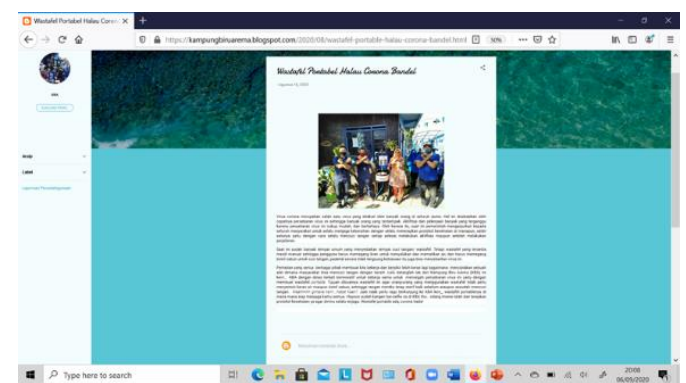

Gambar 3. Contoh tulisan hasil pelatihan yang diposting di blog KBA

Setelah melakukan pendampingan penulisan, tim PkM melakukan analisis terhadap artikel yang diukur dengan melihat unsur substansi isi, struktur, pilihan kata, pengembangan paragraf dan mekanik penulisan. Berikut ini unsur yang diperhatikan dalam tulisan artikel blog peserta pelatihan.

Pertama, kesesuaian tema. Artikel ditulis dengan memperhatikan tema yang telah ditentukan yaitu yang berkaitan dengan kolaborasi perguruan tinggi terutama FIB UB dan apa saja yang telah dilakukan oleh KBA dalam menghadapi situasi pandemi ini. Hal ini ditunjukkan dari ditulisnya artikel dengan judul 'FIB UB dan Promosi Wisata KBA' dan 'Hadapi New Normal KBA Siapkan Protokol Kesehatan'.

Berikutnya, gagasan. Penulis dapat menyajikan gagasan yang relatif baru, menunjukkan pemahaman atas hal yang dibahas, dan aktual sesuai dengan kekinian dengan menyajikan data dan fakta. Sebagian besar artikel dilengkapi dengan gambar yang menunjukkan kegiatan yang dilakukan atau dialami sendiri oleh penulis, misalnya membuat ramuan hand-sanitizer dan mengikuti kegiatan penyemprotan disinfektan yang diadakan KBA.

Aspek penilaian lainnya ialah argumentasi. Sistematika gagasan yang disajikan dalam artikel runtut dan jelas yang terlihat dari ketepatan penggunaan ungkapan yang berkaitan dengan tema yang berisikan unsur informasi dan edukasi.

Yang terakhir ialah aspek penulisan. Format penulisan artikel mengikuti sistematika pendahuluan, isi, dan kesimpulan. Pada artikel yang berjudul 'Doktor Mengabdi FIB UB: Mengubah Tong Sampah Jadi Berkelas', pendahuluan menerangkan kolaborasi FIB UB dengan KBA. Selanjutnya, isi menunjukkan kolaborasi apa yang dimaksud dan bagaimana melakukannya. Dalam hal ini, kolaborasi berupa pelatihan keterampilan teknik lukis tong bekas. Terakhir, artikel ditutup dengan bagaimana pengelolaan barang bekas menjadi produk bernilai ekonomis.

Pemulihan citra pariwisata di KBA dalam menjaga kesehatan di tengah pandemi Covid-
19 dapat berpengaruh terhadap minat wisatawan yang berkunjung pasca pandemi. Upaya pemulihan tersebut dilakukan dengan memanfaatkan media daring untuk tetap mempromosikan destinasi pariwisata dan pemberitaan aktivitas KBA dalam menangani kasus virus Corona bahwa KBA merupakan kampung wisata yang tangguh. Tentu saja dalam praktiknya, KBA didukung oleh beberapa pihak terkait seperti FIB UB dan dinas pariwisata Kota Malang. Hal ini senada dengan apa yang disampaikan oleh Herdiana (2020) bahwa komunikasi dan koordinasi dengan para pelaku usaha pariwisata, pemerhati pariwisata, dan akademisi dalam rangka pemulihan pariwisata pasca COVID-19 perlu dilakukan.

\section{SIMPULAN}

Kegiatan pengabdian kepada masyarakat $(\mathrm{PkM})$ ini dilaksanakan sebagai bagian dari rangkaian Penelitian dan Pengabdian DPP/SPP Fakultas IImu Budaya Universitas Brawijaya. Pengabdian ini merupakan program tahun ke-2 tim PkM dalam revitalisasi media sosial KBA untuk lebih mempromosikan KBA sebagai salah satu kampung wisata di Malang. Pada pelaksanaannya, fokus ditujukan untuk memperbarui isi situs web, dalam hal ini blog KBA. Sebagai kelanjutan dari kegiatan tahun sebelumnya, tim pengabdian dapat melihat bahwa media sosial KBA sudah lebih hidup dan lebih berwarna dengan postingan baru.

Blog resmi yang telah direvitalisasi pada kegiatan PkM kali ini diharapkan mampu mempromosikan KBA dengan lebih baik lagi. Artikel-artikel baru yang ditulis oleh anggota karang taruna KBA juga cukup menarik, sehingga diharapkan para pembaca yang mencari informasi terkait KBA memiliki lebih banyak pengetahuan mengenai KBA. Pada akhirnya, KBA akan semakin dikenal luas dan dapat kembali mendatangkan pengunjung saat situasi pandemi telah mereda.

\section{DAFTAR RUJUKAN}

Asri Sj, N., Fadilah, E., Basith, A.A. (2014). Pelatihan Pemanfaatan Media Sosial untuk Promosi pariwisata dan Potensi Kearifan Lokal di Pantai Sayang Heualang Kab. Garut. Jurnal Pengabdian Kepada Masyarakat, 2 (12), 1-4. Diunduh dari https://jurnal.unpad.ac.id/pkm/article/vi ew/20391/9783

Herdiana, D. (2020). Rekomendasi kebijakan Pemulihan pariwisata Pasca Wabah Corona Virus Disease 2019 (COVID19) di Kota Bandung. (2020). Jurnal JUMPA, 7 (1), 1-30. Diunduh dari 
https://ojs.unud.ac.id/index.php/jumpa/ article/download/61553/35445/ https://doi.org/10.24843/JUMPA.2020. v07.i01.p01.

Indhiarti, T.R, Manipuspika, Y.S, Sudarwati, E. (2020). Pelatihan Pengelolaan Media Sosial Kampung Biru Arema sebagai Media Promosi. ETHOS: Jurnal Penelitian dan Pengabdian kepada Masyarakat, 8 (2), 191-198. Diunduh dari

https://ejournal.unisba.ac.id/index.php/ ethos/article/view/5413

Kertanegara, R. (2018). Penggunaan Clickbait Headline pada Situs Berita dan Gaya Hidup Muslim Dream.co.id. MediaTor: Jurnal Komunikasi, 11 (1), 31-43. https://doi.org/10.29313/mediator.v11i1 .2751

Lidya, F., Sarwoprasodjo, S., \& Hubeis, M. (2020). Gaya Kepemimpinan Transformasional pada Kelompok Wisata Berbasis Komunitas (Studi Kasus Kelompok Ranggon Hills, Desa Gunung Sari Bogor). Sodality: Jurnal Sosiologi Pedesaan, 8 (3), 131-151. Diunduh dari https://journal.ipb.ac.id/index.php/sodal ity/article/view/31764/20940

Morissan. (2010). Periklanan: Komunikasi Pemasaran Terpadu. Jakarta: Kencana Prenada Media Group

Rahayu, S., Dewi, U. \& Fitriana, K. N. (2016). Pengembangan Community-based Tourism sebagai Strategi Pemberdayaan Ekonomi Masyarakat di Kabupaten Kulon Progo, Daerah Istimewa Yogyakarta. Jurnal Penelitian Humaniora, 21 (1), 1-13. Diunduh dari https://journal.uny.ac.id/index.php/hum aniora/article/view/13111

Sari, S., Saddhono, K., Suyitno. (2014). Peningkatan Kualitas Pembelajaran Menulis Dengan Metode Field Trip pada Siswa SMP. Jurnal Penelitian Bahasa, Sastra Indonesia dan Pengajarannya. 1 (3), 540-550. Diunduh dari https://jurnal.fkip.uns.ac.id/index.php/b hs_indonesia/article/view/4050/2849

Sung, T. P. (2012). Developing and Promoting a Highland Community Livelihood for Sustainable Tourism: The case of $\mathrm{Kg}$. Bundutuhan, Ranau, Sabah. Malaysia Journal of Society and Space, 8 (5), 94$99 . \quad$ Diunduh dari http://journalarticle.ukm.my/5517/1/arti kel8.pdf

Widjajanto, K. (2013). Perencanaan Komunikasi: Konsep dan Aplikasi.
Bandung: Ultimus.-.(n.d). https://kampungbiruarema.blogspot.co $\mathrm{m} /$ 